Diabetes and Cancer. Epidemiological Evidence and Molecular Links 


\section{Frontiers in Diabetes}

\section{Vol. 19}

Series Editors

M. Porta Turin

F.M. Matschinsky Philadelphia, Pa. 


\section{Diabetes and Cancer}

Epidemiological Evidence and Molecular Links

Volume Editors

K. Masur Witten

F. Thévenod Witten

K.S. Zänker witten 


\section{Frontiers in Diabetes}

Founded 1981 by F. Belfiore, Catania

Kai Masur, PhD

Institute of Immunology and Experimental

Oncology

University of Witten/Herdecke

Witten, Germany

Kurt S. Zänker, MD, DVM, PhD

Institute of Immunology and Experimental

Oncology

University of Witten/Herdecke

Witten, Germany
Frank Thévenod, MD, PhD

Department of Physiology and

Pathophysiology

University of Witten/Herdecke

Witten, Germany

Library of Congress Cataloging-in-Publication Data

Diabetes and cancer : epidemiological evidence and molecular links /

volume editors, K. Masur, F. Thévenod, K.S. Zänker.

p. ; cm. - (Frontiers in diabetes, ISSN 0251-5342; v. 19)

Includes bibliographical references and index.

ISBN 978-3-8055-8640-5 (hard cover : alk. paper)

1. Diabetes-Epidemiology. 2. Diabetes-Molecular aspects.

3. Metabolic syndrome-Complications. 4. Cancer-Etiology.

I. Masur, K. (Kai) II. Thévenod, F. (Frank) III. Zänker, Kurt S. IV. Series.

[DNLM: 1. Diabetes Mellitus-epidemiology. 2. Diabetes Mellitus-metabolism.

3. Risk Factors. 4. Metabolic Syndrome X-complications.

5. Neoplasms-etiology. W1 FR945X V.19 2008/WK 810 D53715 2008]

RC660.D443 2008

$616.4^{\prime} 6207-\mathrm{dc} 22$

2008025244

Bibliographic Indices. This publication is listed in bibliographic services, including Current Contents ${ }^{\circledR}$ and PubMed/MEDLINE.

Disclaimer. The statements, opinions and data contained in this publication are solely those of the individual authors and contributors and not of the publisher and the editor(s). The appearance of advertisements in the book is not a warranty, endorsement, or approval of the products or services advertised or of their effectiveness, quality or safety. The publisher and the editor(s) disclaim responsibility for any injury to persons or property resulting from any ideas, methods, instructions or products referred to in the content or advertisements.

Drug Dosage. The authors and the publisher have exerted every effort to ensure that drug selection and dosage set forth in this text are in accord with current recommendations and practice at the time of publication. However, in view of ongoing research, changes in government regulations, and the constant flow of information relating to drug therapy and drug reactions, the reader is urged to check the package insert for each drug for any change in indications and dosage and for added warnings and precautions. This is particularly important when the recommended agent is a new and/or infrequently employed drug.

All rights reserved. No part of this publication may be translated into other languages, reproduced or utilized in any form or by any means electronic or mechanical, including photocopying, recording, microcopying, or by any information storage and retrieval system, without permission in writing from the publisher.

(c) Copyright 2008 by S. Karger AG, P.O. Box, CH-4009 Basel (Switzerland)

www.karger.com

Printed in Switzerland on acid-free and non-aging paper (ISO 9706) by Reinhardt Druck, Basel

ISSN 0251-5342

ISBN 978-3-8055-8640-5 


\section{Contents}

VII Preface

Masur, K.; Thévenod, F.; Zänker, K.S. (Witten)

1 Pathophysiology of Diabetes Mellitus Type 2: Roles of Obesity, Insulin Resistance and $\beta$-Cell Dysfunction

Thévenod, F. (Witten)

19 In vivo $\beta$-Cell Imaging in Diabetes, $\boldsymbol{\beta}$-Cell Hyperplasia, and Insulinoma Gotthardt, M. (Nijmegen); Béhé, M. (Marburg); Lasser, T. (Lausanne)

30 Incretin-Based Therapies for the Treatment of Type 2

Diabetes - DPP-4 Inhibitors and Incretin Mimetics

Gallwitz, B. (Tübingen)

44 Janus Face of Glucose and Glucose-Regulating Hormones Masur, K. (Witten)

59 Role of Glucose Metabolism in Carcinogenesis and Cancer Progression Gatenby, R.A. (Tampa, Fla.)

71 Glucose Transporters: Their Abnormalities and Significance in Type 2 Diabetes and Cancer Schürmann, A. (Nuthetal)

84 The Epidemiologic Relationship between Diabetes and Cancer Zänker, K.S. (Witten)

97 Diabetes Mellitus and Breast Cancer Wolf, l.; Rubinek, T. (Ramat Gan/Tel Aviv)

114 Nutrition, Diabetes, and Cancer LaValle, J.B. (Cincinnati, Ohio)

134 Diabetes and Cancer: The Road Ahead Masur, K.; Thévenod, F.; Zänker, K.S. (Witten)

145 Subject Index 



\section{Preface}

This book was made possible by the contributions of leading experimental scientists and clinicians from newly upcoming and interdisciplinary fields of research concerning the common molecular and clinical features of chronic diseases. Chronic disease represents the main cause of mortality in developed countries. The increase in its prevalence is associated with changes in lifestyle habits and related risk factors such as tobacco use, physical inactivity, overweight and obesity, and poor nutrition. Collectively, cardiovascular diseases, cancer and diabetes/metabolic syndrome ranking first among the ten leading causes of death - are responsible for more than 25 million deaths in the Western world each year. Much of this disease burden could be prevented, however, by controlling the modifiable risk factors.

The present trend of progressively lengthening lifespan in all social groups of Western societies reflects the changing pattern of mortality from formerly untreatable infectious diseases to chronic (degenerative) diseases. Predictions for the continuing lengthening of the lifespan of the class of 2005 and succeeding classes may be jeopardized by the alarming increase in obesity, for example, which worsens the incidence of cardiovascular disorders, diabetes and cancer.

The recent discoveries of epidemiological and molecular links between the diabetes/ metabolic syndrome and cancer originated from interdisciplinary-oriented researchers revealing roles in biological processes that are likewise varied. The diabetes/ metabolic syndrome is like the wolf in sheep's clothing - by the time it has been diagnosed, most subjects might already have an established chronic disease, like cardiovascular disease and cancer. The most recent findings suggest a connection between inflammation and chronic disease, such as insulin resistance associated with diabetes and cancer, which had not or only inadequately been appreciated previously. 
The following distinguished authors guarantee that this book is at the forefront of experimental and clinical research in diabetes and cancer, and offers the reader novel insights into the interdisciplinary approaches of tomorrow: F. Thévenod (Witten, Germany) introduces the state of the art of the pathophysiology of type 2 diabetes. M. Gotthard (Nijmegen, The Netherlands) addresses new issues of in vivo imaging of the $\beta$-cell and insulinoma. B. Gallwitz (Tübingen, Germany) reviews the most advanced therapy strategies embarking on incretins and DPP4 inhibitors. K. Masur (Witten, Germany) bridges on a molecular level diabetes and cancer with specific reference to glucose and glucose-regulating hormones. R. Gatenby (Moffitt Cancer Center, Tampa, Fla., USA) clearly demonstrates that the 'Warburg effect' has to be reconsidered to understand the energetic metabolism of tumor cells. A. Schürmann (Potsdam-Rehbrücke, Germany) describes the glucose transporter systems and shows their abnormalities and significance in type 2 diabetes and cancer. K.S. Zänker (Witten, Germany) summarizes the epidemiology and molecular epidemiology of type 2 diabetes and cancer. I. Wolf (Tel-Hashomer, Israel) points at the increased risk of breast cancer in relationship to type 2 diabetes. J. LaValle (Pittsburgh, Pa., USA) describes the metabolic spiral, which leads to chronic disease. Finally, the editors of this book (K.M., F.T., K.S.Z) advocate the efforts of Beaglehole et al. [Lancet 2007;370:2152-2157] who have established the Chronic Disease Action Group to encourage, support, and monitor action on the implementation of an evidence-based effort to promote global, regional, and national action to prevent and control chronic disease.

This book should encourage scientists and physicians - working separately on various aspects of the illnesses with the highest predicted mortality in the 21st century - to come together and combine their therapies and strategies. Since the health problems mentioned may be merged with the overall topic 'metabolic syndrome', the common goal should be early detection at the first signs indicating the onset of a metabolic misbalance in order to prevent the consecutive cascades which lead to metabolic syndrome, resulting in the so-called diseases of modern civilization - cancer, diabetes and hypertension.

This volume of Frontiers in Diabetes, 'Diabetes and Cancer - Epidemiological Evidence and Molecular Links', demonstrates why that it is necessary to reflect on the different aspects of an illness and that it is worthwhile checking for metabolic derangements in order to find an early therapy combining approaches devised by specialists working in different fields.

The Editors of this book are grateful to Karger Publishers, Switzerland, and to F.M. Matschinsky (Philadelphia, Pa., USA) and M. Porta (Turin, Italy), the Editors-in-Chief of the long-standing and well-recognized series of Frontiers in Diabetes, for publishing this volume.

Kai Masur, Witten Frank Thévenod, Witten Kurt S. Zänker, Witten 